\title{
The Impact of Foreign Direct Investment on Economic Growth in Nigeria
}

\author{
Sani Ali Ibrahim, Hussin Abdullah \\ Northwest University, Kano, Nigeria \\ School of Economics, Finance and Baniking, Universiti Utara Malaysia \\ ibrahimali018@gmail.com
}

\begin{abstract}
The economic development performance can be used to measure the economic growth of a given country. In economic analysis, a country can attain economic growth through the growth in national income measurement. However, there were rigorous discussions on the role of foreign direct investment (FDI) on economic growth and continued to be a topic of discussion on the contemporary economy. This paper serves as an extension to the previous empirical studies on the issue by providing some evidence from time series data for the period 1971 to 2013 of Nigeria. The primary aim of this study is to analyze the impact of FDI on economic growth of Nigeria taking trade openness, Gross Fixed Capital Formation and human capital as control variables. To investigate the long run equilibrium relationship, Johansen and Juselius co-integration approach is analyzed, while the speed of adjustment in the short run is analyzed through the use of VECM method. In Nigeria, FDI, GFCF and HK have long run relationship with economic growth. However, the coefficient of ECM in Nigeria is statistically significant at $1 \%$ level of significance. Thus, $10.8 \%$ of the adjustment is achieved due to the correction of the adjustment speed in a year.
\end{abstract}

Keywords: FDI, Trade openness, Gross fixed Capital formation, Human capital, VECM

\section{Introduction}

It has been observed that most of the nations are geared towards development and gaining effective participation of international economic organization with the advent of Foreign Direct investment (FDI). FDI determine the inter-relationship between a country and another that can carry a long period of time. Normally, participation comes in the form of management, joint venture, transfer of technology and expertise (Agrawal \& Khan, 2011). According to OECD (2008), FDI promotes the direct investors' interest as a class of business enterprise in another country. However, the aim of the enterprise signifies the long-run participation that will exist between the direct investment enterprise and direct investor. Thus, there is high expectation of persuasion on the management of the enterprise. Therefore, the statistical evidence of such a relationship is the $10 \%$ or more direct or indirect ownership of the voting power of an enterprise resident in one economy by an investor resident in another economy. For many years FDI has been playing a vital role on economic growth. There were lots of discussions on the relationship between FDI and economic growth in both present and past theoretical and empirical literatures. However, most of the analyses conducted on FDI and economic growth focus on the traditional neo-classical and the endogenous growth theories. In recent time with the coming of endogenous theories it has come to the notice that FDI has taken into account as one of the long run economic growth determinants (Barro \& Sala-i-Martin, 2004).

Trends in FDI Flows: Figure 1 shows that FDI flows increased by $9 \%$ in developed economies to $\$ 566$ billion maintaining $39 \%$ of the global flows as the developing nations acquired $54 \%$ of the total with $\$ 778$ billion in 2013. The transition economies got the remaining of $\$ 108$ billion. More than a decade, Africa got $26 \%$ share of the extractive industry in the value of Greenfield projects while LDCs got $36 \%$. However, the shares of the value of announced projects in both Africa and LDCs are declining rapidly with manufacturing and services constitute $90 \%$. 
Figure 1: FDI inflow shares by major economic groupings (Percent)

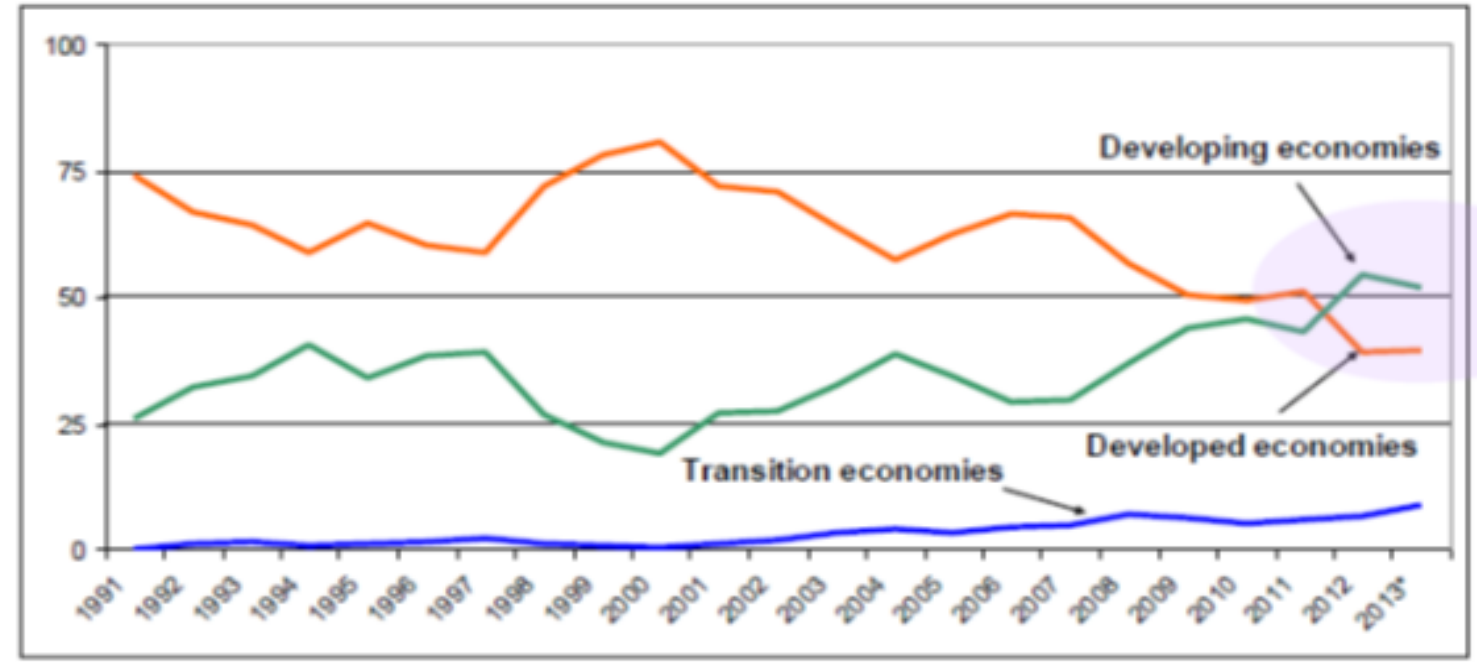

Source: World Investment Report (UNCTAD, 2014).

Thus, Nigeria as was viewed to be the "giant" of Africa continues to be the focus region at which the portion of FDI flows to Africa remains an issue of concern. Hence, real foreign direct investment was said to have been fluctuating into Nigerian economy for over a period of time as shown in (Figure 2). After the implementation of "Structural Adjustment Program" (SAP) in 1986, and the subsequent liberalization of some aspects of the economy, FDI continue to be on an increasing trend ranging from $\$ 1.93$ billion in 1986 to as high as $\$ 8.55$ billion in the year 2009 (UNCTAD, 2014).

Figure 2: FDI inflow in Nigeria (US \$ million)

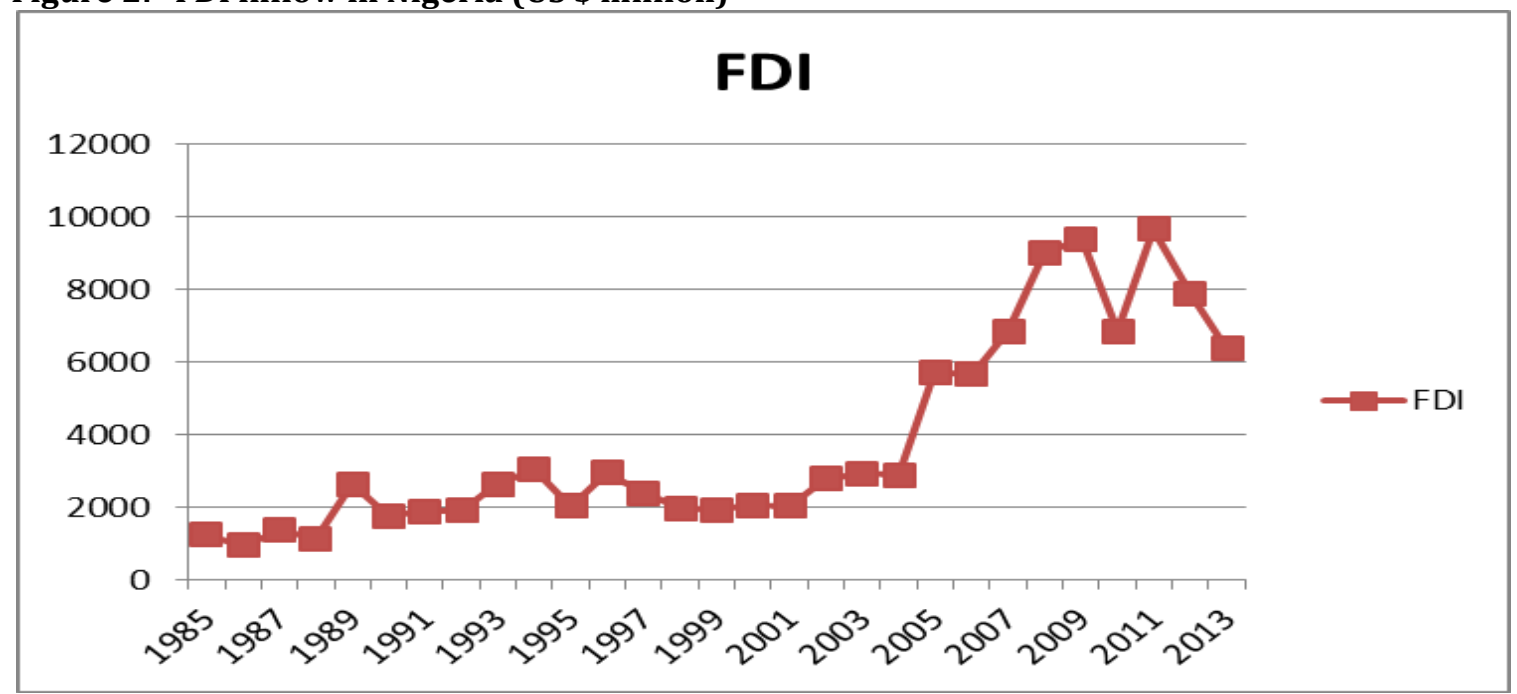

Source: World Development Indicator, 2014

Foreign direct investment (FDI) into Nigeria fell to about $\$ 6.05$ billion in 2010 due to the global economic crisis and uncertainty over a petroleum industry bill which is perceived as unfavorable to transnational corporations (Ojo, 2012). The Nigerian annual growth rate of GDP in 2010 fourth quarter was 8.60 percent at the high rate and 3.46 percent at the lower rate in 2012 first quarter. Thus, GDP of Nigeria was said to be persisted to 7.67 percent in 2013 last quarter as it was previously revised in 2012 as 6.81 percent and 6.99 percent in 2013 third quarter. However, the estimated growth rate of 2012 which is 6.58 percent rose to 6.87 
percent in 2013. Hence, the average annual growth rate of Nigeria between 2005 and 2014 was estimated to be 6.13 percent.

Since the mid-1970s, however, developed countries have attracted the bulk of FDI and correspondingly, the developing countries failed to create an enabling environment for foreign investors. The 1980s and 1990s have seen considerable changes in the level and composition of FDI in the developing countries. Macaulay (2003) made it known that effort has been made to encourage foreign direct investment into the economy by foreign investors, yet there are some that do not show interest to come to Nigeria because of some lingering problems in the economy such as poor infrastructural facilities, corruption and insecurity. However, the recent fact depicts that the relationship between FDI and economic growth may be period and country specific which makes such relation to be inconclusive (Baharumshah \& Law, 2010). Thus, the need to investigate on their relationship is highly essential. Hence, the research is set out to investigate the impact of FDI on economic growth in Nigeria.

\section{Literature Reviews}

The economic growth of an economy is said to be the increase in the amount of the goods and services produced over a period of time. Thus, each nation has a different economic growth. As the economists are trying to make an effort to appreciate why countries are growing at different rates; the study of economic growth models is highly essential. There are lots of researches being studied by many researchers worldwide using different approaches to analyze the relationship between FDI and economic growth. However, the findings of the researchers yielded inconsistent results. Hooi \& Wah (2010) took a study on the relationships between FDI, domestic investment and economic growth in Malaysia from 1970 to 2009. In order to identify the possible long-run equilibrium relationship among the variables they employ the Johansen-Juselius multivariate co-integration test in vector autoregressive system. The findings conclude that the real output will increase in the long-run with increase in FDI. From the study of Parviz (2011) on the economic growth determinants in Canada using the Beach-Mackinnon approach in estimating his model employing annual data for the period 1976 to 2008, he found out that FDI is insignificant but has a positive relationship. This shows that FDI does not influence economic growth in Canada. However, total factor productivity and domestic investment are the main determinants of economic growth in Canada. Also, a study being examined on the impact of economic growth of Malaysia on FDI revealed that GDP and FDI have no positive relationship. Although, there is positive relationship between FDI and GDP related to manufacturing sector but there was no such relationship in financial sector (Nabi \& Malarvizhi, 2014).

Zakari, Mohammed \& Adamu (2012) examine the role of FDI on economic growth and make a comparison among selected countries of Africa and Asia and employ panel regression for the period 1990 to 2009 by considering 15 countries from each region making 30 countries as a whole. They made their analysis in two ways. Their first analysis was on the aggregate data and subsequently disaggregates data by taking each region into consideration so as to have a peculiar assessment on the impact of FDI on economic growth from each region. From their empirical result from both Africa and Asia, FDI has positive relationship with GDP growth. Also, there was an evidence of one-way causality to only African region but in Asia there was no evidence of such causality. Thus, FDI promotes economic growth. Ismail, Saadiah, Ridzuan \& Ahmed (2014) carried out an investigation via the modification of standard Cobb Douglass production function by employing Autoregressive Distributive Lag technique on the relationship between FDI and Export on the economic growth of Malaysia for the period 1980 to 2011. Though, export promotes growth more, but FDI also contributed to the economic growth of Malaysia and both have positive correlation with growth most importantly in the long run. Similarly, a study was carried out by Zaheer \& Bashir (2011) on the role of FDI and trade openness on economic growth in Pakistan and Malaysia employing Johansen co-integration test and Granger causality test to examine the relationship and determining the direction of causality respectively for the period of 1980 to 2010. In Pakistan there is no significant impact of FDI and exchange rate on its economic growth.

Agrawal \& Khan (2011) examined the effect of FDI on economic growth of China and India and the result revealed that FDI impacted significantly on GDP growth in China more than that of India. The main reason at which economic growth in China is more affected by FDI is due to the large size of its market, high level of 
infrastructures, labor efficiency and government support. Saqib, Masnoon \& Rafique (2013) analyzed the impact of FDI on economic growth of Pakistan for the period of 1981- 2010 where the variables studied have long-run relationship. However, FDI in Pakistan impacted negatively on its economic growth. However, a comparative study between South Asian countries and China to analyze the impact of FDI and their economic growth using annual data was tested using granger causality test. The findings show that China's economy is moving faster compared to that of economic growth of Asian countries considered under study (Bashir, Mansha, Zulfiqar \& Riaz, 2014). In addition to their finding, there was negative impact of FDI on economic growth in Bangladesh, India and Pakistan. Adams (2009) suggested that FDI is necessary but not a sufficient condition in determining economic growth in Sub-Saharan Africa. Jadhav (2012) analyzed the determinants of FDI in the economy of Brazil, Russia, India, China and South Africa employing panel data for the period 2000 to 20009 and suggested that the economic factors in these countries impacted more significantly on FDI than the political and institutional factors. However, analysis on the impact of FDI on Nigerian economic growth for the period 1970 to 2001 applying error correction model revealed that private capital and lagged foreign capital have little, hence the impact on the economic growth are not statistically significant. In addition, both labor force and human capital play a vital role in enhancing economic growth in Nigeria (Akinlo, 2004).

Baharumshah \& Law (2010) examine the relationship between FDI, economic freedom and economic growth in 85 countries using panel data based on the Generalized Method of Moments approach for the period 1976 to 2004. From the empirical findings, economic freedom promotes and has positive impact on the economic growth, whereas FDI does not have positive impact in the host countries. Saqib, Masnoon \& Rafique (2013) analyzed the impact of FDI on economic growth of Pakistan for the period of 1981- 2010 where the variables studied have long-run relationship. However, FDI in Pakistan has a negative and significant impact on its economic growth. Hassen \& Anis (2012) analyzed the relationship between FDI and economic growth of Tunisia employing time series data for the period 1975 to 2009 and found that FDI can enhance economic growth of Tunisia especially in the long-run. Moreover, the economic growth of Tunisia is negatively affected by the trade openness. The negative effect of trade openness on economic growth is due to the fact that Tunisia economy is engaged mainly in the exporting primary products.

\section{Methodology}

This study will discuss on the empirical analysis and annual time series data of 1971 to 2013 will be applied to analyze the relationship between FDI and some other variables like Trade openness, Gross Fixed Capital Formation and Human Capital on GDP in Nigeria.

Therefore, the GDP functions above can simply be specified as model below:

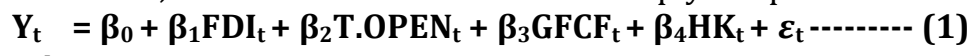

Where;

GDP

FDI

T.OPEN

GFCF

$\mathrm{HK}$

$\beta$

$\mathrm{t}$

$\mathcal{E}$
$=$ Gross Domestic Product

= Foreign Direct Investment

$=$ Trade Openness

$=$ Gross Fixed Capital Formation

= Human Capital

$=$ the parameter for the explanatory variables

$=$ time series

= error term

Unit root test: Unit root test is key factor when ascertaining the stationarity of time series data of a given study. Therefore, series can be regarded as stationary if it does not have problem of unit root. However, the characteristic equation of the process of unit root 1 is said to be non-stationary in the linear stochastic process. In other words, if the characteristic equation of the other roots fall within the unit circle at which the absolute value is less than one, the process will be stationary when taking the first difference. In estimating the slope coefficients, unit root should first be tested by taken the null hypothesis as there is presence of unit root. Therefore, we can use OLS if we reject the null hypothesis. But, if we do not reject the null hypothesis, the difference operator to the series can then be applied as shown in the equation below:

$\Delta \mathbf{Y}_{\mathbf{t}}$ 
However, the unit root test that will be used for this study to ascertain the stationarity of the variables of interest is Augmented Dickey-Fuller (ADF) test. ADF test is a test for a unit root in a time series data which serves as an augmented version of Dickey-Fuller test. Thus, the equation of ADF test specification is given below:

$\Delta \mathbf{Y}_{\mathbf{t}}$

$$
=\beta_{1}+\beta_{2} \mathrm{t}+\delta \mathrm{Y}_{\mathrm{t}-1}+\alpha i \Delta \mathrm{Y}_{\mathrm{t}-1}+\varepsilon_{\mathrm{t}}-\cdots-\cdots
$$

Where $Y_{t}$ is the variable of the model of the study, the differencing operator is denoted by $\Delta$, the time trend is denoted by $\mathrm{t}$ and $\varepsilon$ is the error term which is normally distributed with zero mean and constant variance. Hence, $\boldsymbol{\beta}_{\mathbf{1}}, \boldsymbol{\beta}_{\mathbf{2}}$ and $\boldsymbol{\delta}$ as well as $\boldsymbol{\alpha i}$ are the set of parameters that will be estimated from the equation. However, the null hypothesis and the alternative hypothesis in unit root from the above equation can be as follows:

$\mathrm{H}_{\mathrm{o}}: \delta=\left(\mathrm{Y}_{\mathrm{t}}\right.$ is non-stationary)

$\mathrm{H}_{1}: \delta=$ (Y $\mathrm{t}$ is stationary)

Based on the test, we can reject null hypothesis if the t-test statistic has a negative values lower than the tabulated critical value. On the other hand, we do not reject null hypothesis if $\boldsymbol{\delta}$ is found to be equal to zero. This shows that there is presence of unit root and therefore $Y_{t}$ is non-stationary.

Johansen and Juselius (JJ)Co-integration Test: The aim of (JJ) co-integration test is to ascertain the long run equilibrium relationship that may exist among the variables of this study. Hence, if time series data are stationary, we can test for a long run relationship among variables of interest using Johansen (1988) and Johansen and Juselius (JJ) (1990) methods. This involves the test of co-integration vectors.

$\mathbf{Y}_{\mathrm{t}}$

$$
=\Pi_{1} \mathbf{Y}_{\mathrm{t}-1}+\Pi_{2} \mathbf{Y}_{\mathrm{t}-2}+\ldots .+\Pi_{\mathrm{k}} \mathbf{Y}_{\mathrm{t}-\mathrm{k}}+\boldsymbol{\varepsilon}_{\mathrm{t}} \quad \mathrm{t}=1,2 \ldots, \mathrm{n}---(\mathbf{4})
$$

Where $\mathbf{Y}_{\mathrm{t}}$ is $\mathrm{N} \times 1$ vector of stochastic variable, $\boldsymbol{\Pi}_{1}, \boldsymbol{\Pi}_{2}, \ldots, \boldsymbol{\Pi}_{\mathrm{k}}$ is the $\mathrm{n} \times \mathrm{n}$ parameter and $\boldsymbol{\varepsilon}_{\mathrm{t}}$ is the random error. The matrix $\Pi$ indicates the long run equilibrium relationship between $\rho$ variables which can further be break down into two matrices, i.e. $A$ and $B$, such that $\Pi=A B$.A is referred to as vector error correction parameter while $B$ is the co-integrating vector. Therefore, the process can be used to test the existence of a long run equilibrium relationship among GDP, FDI, T.OPEN, GFCF and HK variables in equation (1).

However, this study will employ Trace (Tr) Eigen value statistic and Maximum (L-max) Eigen value statistic for the trace is written as follows:

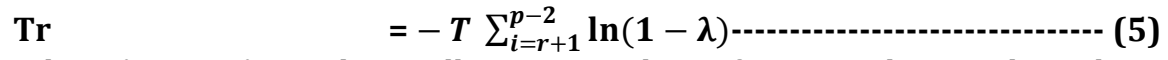

Where $\lambda_{r+1} \ldots . . \lambda_{p}$ are the smallest Eigen values of estimated $p-r$. The $H_{0}$ hypothesis for the Trace Eigen value test is that there are at most $r$ co-integrating vectors (Johansen \& Juselius, 1990).

On the other hand, the L-max could be calculated as:

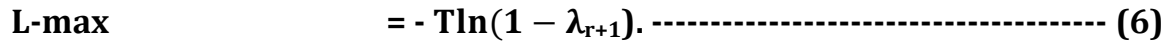

The $\mathrm{H}_{0}$ hypothesis for the maximum Eigen value test is that $\mathrm{r}$ co-integrating vectors are tested against the $\mathrm{H}_{1}$ hypothesis of $r+1$ co-integrating vectors. If Trace Eigen value test and maximum Eigen value test yield different results, the results of the maximum Eigen value test should be used because the power of the maximum Eigen value test is considered greater than the power of the Trace Eigen value test (Johansen \&Juselius, 1990).

Vector Error Correction Model (VECM): A Vector Error Correction Model is a dynamical system with the characteristics that the deviation of the present state will be fed into its short run dynamics from its long run relationship. Therefore, VECM is said to be a peculiar instance of the Vector Auto-regression (VAR) for the variables that have been integrated of order one I(1) which are said to be stationary when taken their first differences. Hence, VECM considers variables that have co-integrating relationships. However, we can simply say that there is existence of long run equilibrium relationship between series, if we can discover the cointegration relationship between them and therefore we can assess the short run properties by employing VECM. Moreover, VECM can be estimated by applying VAR approach. In other words, we can establish VECM by showing changes in the dependent variables which function as the level of disequilibrium in the cointegrating relationship and the independent variables through error correction term. Therefore, we can develop our vector error correction model as follows:

$\Delta \operatorname{lnGDP}_{\mathrm{t}}=\lambda_{0}+\lambda_{1} \Delta \operatorname{lnFDI}_{\mathrm{t}}+\lambda_{2} \Delta$ T.OPEN $_{\mathrm{t}}+\lambda_{3} \Delta \mathrm{GFCF}_{\mathrm{t}}+\lambda_{4} \Delta \mathrm{HK}_{\mathrm{t}}+\lambda_{5} \mathrm{ECM}_{-1}+v_{\mathrm{t}}--$ (7) 
From the above equation, ECM-1 is the error correction component which is also the estimation of the lagged error series and $v_{\mathrm{t}}$ is the random error term. However, the adjustment speed of the model of this study will be expressed by this method.

\section{Findings}

Table 1: Unit Root Test Results

\begin{tabular}{|c|c|c|c|c|c|c|}
\hline \multirow[t]{3}{*}{ Country } & \multirow[t]{3}{*}{ Variables } & \multicolumn{5}{|c|}{ Augmented Dickey Fuller (ADF) Test } \\
\hline & & \multicolumn{3}{|c|}{ Level } & \multicolumn{2}{|l|}{ First Difference } \\
\hline & & Constant & $\begin{array}{l}\text { Constant } \\
\text { Trend }\end{array}$ & and & Constant & $\begin{array}{l}\text { Constant } \\
\text { Trend }\end{array}$ \\
\hline \multirow[t]{10}{*}{ NIGERIA } & GDP & $0.1625[9]$ & -0.64139[] & & $-5.7638[9]$ & $-5.8343[9]$ \\
\hline & & $(0.9668)$ & $(0.9710)$ & & $(0.0000)^{* * *}$ & $(0.0001)^{* * *}$ \\
\hline & FDI & $-1.4498[9]$ & $-1.8712[9]$ & & $-7.8253[9]$ & $-10.1094[9]$ \\
\hline & & $(0.5480)$ & $(0.6501)$ & & $(0.0000)^{* * *}$ & $(0.0000)^{* *}$ \\
\hline & T.OPEN & $-2.6374[9]$ & $-2.4728[9]$ & & $-8.6436[9]$ & $-8.8739[9]$ \\
\hline & & $(0.0937)$ & $(0.3393)$ & & $(0.0000)^{* * *}$ & $(0.0000)^{* * *}$ \\
\hline & GFCF & $-2.8893[1]$ & $-1.0853[9]$ & & $-3.5741[1]$ & $-5.5782[9]$ \\
\hline & & $(0.0553)$ & $(0.9190)$ & & $(0.0107)^{* *}$ & $(0.0002)^{* * *}$ \\
\hline & $\mathrm{HK}$ & $-2.3701[9]$ & $-0.0019[9]$ & & $-3.3428[9]$ & $-4.2507[9]$ \\
\hline & & $(0.1570)$ & $(0.9947)$ & & $(0.0199)^{* *}$ & $(0.0096)^{* * *}$ \\
\hline
\end{tabular}

Notes: ${ }^{* * *}$ and ${ }^{* *}$ indicate the rejection of the null hypothesis of non-stationary at $1 \%$ and $5 \%$ level of significance respectively.

[] indicates the lag specification

0 indicates the t-statistic

The t-statistics for all variables in Table 1 show that they are statistically not significant which indicate that null hypothesis cannot be rejected. Hence, at level all the variables are non-stationary. In addition, unit root is said to be found in all the variables in this study. On the other hand, at first difference ADF test is used and the result show that all the variables show that all the variables are statistically significant. Therefore, null hypothesis in this case can be rejected. This result confirms that all the series in this study are integrated of order one I(1) and can therefore conclude to have no unit root. However, the Johansen and Juselius Cointegration test for the period 1971 to 2013 is shown in Table 2. The lag length of order 1 is selected on the basis of the minimum value of Shwartz Information Criterion (SIC). However, Trace test shows 3 cointegrating equations at $1 \%$ and $5 \%$ level of significance, while Max-Eigen value test shows 1 co-integrating equation at $5 \%$ level of significance. Therefore, Max-Eigen value test will be considered, as it has more power than Trace test as suggested earlier in the methodology. Thus, it will be concluded that there is one cointegrating equation in Nigeria at $5 \%$ level of significance. To put it further, there exist long run relationship among FDI, T.OPEN, GFCF AND HK and economic growth in both the countries.

Table 2: The Johansen-Juselius Co-integration Test Results

\begin{tabular}{lllllll}
\hline Country & $\mathbf{H}_{\mathbf{0}}$ & $\mathbf{H}_{\mathbf{1}}$ & $\begin{array}{l}\text { Max-Eigen } \\
\text { Statistic }\end{array}$ & $\begin{array}{l}\text { Critical Value } \\
\text { (Eigen) at 5\% }\end{array}$ & Trace Statistic & $\begin{array}{l}\text { Critical Value (Trace) } \\
\text { at 5\% }\end{array}$ \\
\hline NIGERIA & $\mathrm{r}=0$ & $\mathrm{r}=0$ & $31.14321^{* * *}$ & 30.43961 & $74.57450^{* * *}$ & 60.06141 \\
& $\mathrm{r} \leq 1$ & $\mathrm{r}>1$ & 17.8858 & 24.15921 & $43.43129^{* *}$ & 40.17493 \\
& $\mathrm{r} \leq 2$ & $\mathrm{r}>2$ & 14.85344 & 17.79730 & $25.54540^{* * *}$ & 24.27596 \\
& $\mathrm{r} \leq 3$ & $\mathrm{r}>3$ & 7.06984 & 11.22480 & 10.69196 & 12.32090 \\
& $\mathrm{r} \leq 4$ & $\mathrm{r}>4$ & 3.62212 & 4.12991 & 3.62212 & 4.12991 \\
\hline
\end{tabular}

Note: ${ }^{* * *}$ and ${ }^{* *}$ indicate the rejection of the null hypothesis of non-stationary at $1 \%$ and $5 \%$ level of significance respectively.

Table 3 shows the co-integration results which reveal that FDI, GFCF and HK are the variables that are statistically significant and therefore have long run relationship with economic growth. FDI in Nigeria is 
statistically significant but has negative effect on its economic growth. This implies that $1 \%$ increase in FDI will lead GDP to reduce by $0.92 \%$.

Table 3: Co-integration Result for the Growth Model

\begin{tabular}{llll}
\hline Country & Variable & Coefficient & t-statistic \\
\hline NIGERIA & LFDI & -0.918455 & $10.3780^{* * *}$ \\
& T.OPEN & -0.857724 & 0.4837 \\
& GFCF & 0.176975 & $6.84623^{* * *}$ \\
& HK & $2.16 \mathrm{E}-06$ & $6.96774^{* * *}$ \\
\hline
\end{tabular}

Note: ${ }^{* * *}$ and ${ }^{* *}$ indicate significant at $1 \%$ and $5 \%$ level of significance respectively.

Perhaps, the negative impact of FDI on Nigerian economy is due to the inappropriate capital-intensive techniques. Also, the economy is characterized with labor-intensive and the foreign investors are there for the exploitation of raw materials being endowed by the economy for the finished products in their countries. It can also be attributed to fear anticipation of political instability. On the other hand, the result for GFCF is positive and statistically significant. That is to say $1 \%$ increase will cause GDP to rise by $0.18 \%$. Therefore, the increase in GFCF will promote productive capacity of various economic units by raising the number of firms. Thus, cost of production will be minimized and productivity of factor endowments will be enhanced. Also, HK result reveals positive and statistically significant. Therefore, an increase in $\mathrm{HK}$ by $1 \%$ will cause GDP to rise by $0.2 \%$. As with the study of Akinlo (2004), HK is positive with Nigerian economic growth and made a recommendation that Nigerian economy should promote the stock of human capital through an educational policy which in the long run will enhance the economic growth.

Table 4: VECM Result for the Growth Model

\begin{tabular}{llll}
\hline Country & Variable & Coefficient & t-statistic \\
\hline NIGERIA & D(LFDI) & 0.07466 & -0.49546 \\
& D(T.OPEN) & 0.01424 & 0.96296 \\
& D(GFCF) & 0.64216 & 1.85469 \\
& D(HK) & 6.2475 & 1.33357 \\
& ECM(-1) & -0.10850 & $-3.25984^{* * *}$ \\
\hline
\end{tabular}

Note: ${ }^{* * *}$ and ${ }^{* *}$ indicate $1 \%$, and $5 \%$ level of significance respectively.

All the variables are not affecting GDP in the short run in Nigerian context. That is, none of the variables are statistically significant. However, the coefficient of error correction is statistically significant at $1 \%$ level of significance with -0.108497 . Therefore, $10.8 \%$ of the adjustment is achieved due to correction adjustment speed in a year.

\section{Conclusion and Policy Implications}

The primary objective of this study is to analyze the impact of FDI on economic growth of Nigeria taking trade openness, Gross Fixed Capital Formation and human capital as control variables for the period 1971 to 2013. To analyze the long run equilibrium relationship, Johansen and Juselius co-integration approach is analyzed, as the speed of adjustment in the short run is analyzed through the use of VECM method. FDI, GFCF and HK have long run relationship with economic growth. However, FDI is found to be statistically significant but has negative effect on the economic growth. This implies that increase in FDI will lead GDP to fall. On the contrary, both GFCF and HK are statistically significant and positive. Consequently, both GFCF and HK have positive impact on the Nigerian economy. However, the result on FDI is in line with the studies of Bashir, Mansha, Zulfiqar \& Riaz (2014) which found negative in Bangladesh, India and Pakistan during the period under study, Nabi \& Malarvizhi (2014), Baharumsha \& Law (2010) and Saqib, Masnoon \& Rafique (2013). Nigeria as part of developing countries is endowed with natural resources that can be harnessed through capital formation. To this effect, dependency on foreign investment should remain limited and therefore utilize domestic investment that will benefit the country's economy. Therefore, the government of Nigeria should formulate economic policies that will encourage domestic saving and investment and therefore limiting FDI inflows into the countries. Thus, the benefits of foreign investment appear to be taken out to the investor country than re-investing in the host country. 


\section{References}

Adams, S. (2009). Can Foreign Direct Investment (FDI) Help to Promote Growth in Africa? African Journal of Business Management, 3(5), 178-183.

Agrawal, G. \& Khan, M. A. (2011). Impact of FDI on GDP: A Comparative study of China and India. International Journal of Business and Management, 6(10), 71-79.

Akinlo, A. E. (2004). Foreign Direct Investment and Growth in Nigeria: An Empirical Investigation. Journal of Policy Modeling, 26, 627-639.

Baharumshah, A. Z. \& Law, S. H. (2010). Foreign Direct Investment, Economic Freedom and Economic Growth: International Evidence. Economic Modelling, 27(5), 1079-1089.

Barro, R. J. \& Sala-i-Martin, X. (2004). Economic Growth, (2nd ed), London, The MIIT Press Cambridge.

Bashir, T., Mansha, A., Zulfiqar, R. \& Riaz, R. (2014). Impact of FDI on Economic Growth: A Comparison of South Asian States \& China. European Scientific Journal, 10(1), 446-469.

Hassen, S. \& Anis, O. (2012). Foreign Direct Investment (FDI) and Economic Growth: An Approach in terms of Cointegration for the Case of Tunisia. Journal of Applied Finance \& Banking, 2(4), 193-207.

Hooi, L. H. \& Wah, T. B. (2010). Linkages between Foreign Direct Investment. Domestic Investment and Economic Growth in Malaysia, 2, 48-57.

Ismail, M., Saadiah, M., Ridzuan, A. R. \& Ahmed, E. M. (2014). The Export Led-Growth and FDI Led-Growth Nexus in Malaysia: Evidence from ARDL Analysis. Advances in Research, 2(5), 240-249.

Jadhav, P. (2012). Determinants of Foreign Direct Investment in BRICS Economies: Analysis of Economic, Institutional and Political Factor. Procedia - Social and Behavioral Sciences, 37, 5-14.

Johansen, S. \& Juselius, K. (1990). Maximum Likelihood Estimation and Inference on Cointegration - with Applications to the Demand for Money. Oxford Bulletin of Economics and Statistics, 52(2), 169-210.

Macaulay, E. D. (2003). Foreign Direct Investment and the Performance of the Nigerian Economy.In 1st International Technology, Education and Environment Conference (ASSR)

Nabi, M. H. \& Malarvizhi, C. (2014). Impact of GDP and Exchange Rate on Foreign Direct Investment in Malaysia. Australian Journal of Basic and Applied Sciences, 8(1), 473-478.

OECD. (2008). Benchmark Definition of Foreign Direct Investment, Report, (4th ed), OECD.

Ojo, A. S. (2012). Foreign Direct Investment (FDI) Trends in Developing Nations: Nigeria Experience in a Globalization Era. International Business and Management, 4(1), 146-156.

Parviz, A. (2011). Economic Growth Determinants and Foreign Direct Investment: Causality in Canada. International Journal of Business and Social Science, 2(11), 1-9.

Saqib, N., Masnoon, M. \& Rafique, N. (2013). Impact of Foreign Direct Investment on Economic Growth of Pakistan. Advances in Management \& Applied Economics, 3(1), 35-45.

UNCTAD. (2014). Investing in the SDGs: An Action Plan, Report, New York and Geneva.

Zaheer, K. K. \& Bashir, A. K. (2011). Impact of FDI and Trade Openness on Economic Growth: A Comparative Study of Pakistan and Malaysia. Theoretical and Applied Economics, 17(11), 53-58.

Zakari, A. Y., Mohammed, A. H. \& Adamu, Y. M. (2012). Does FDI Cause Economic Growth? Evidence from Selected Countries in Africa and Asia. African Journal of Social Sciences, 2(4), 114-124. 